\title{
How far does the apple fall from the tree? The size of English bank branch networks in the nineteenth century
}

Article

Accepted Version

Newton, L. and Barnes, V. (2018) How far does the apple fall from the tree? The size of English bank branch networks in the nineteenth century. Business History, 60 (4). pp. 447-473. ISSN 1743-7938 doi:

https://doi.org/10.1080/00076791.2017.1323883 Available at https://centaur.reading.ac.uk/66819/

It is advisable to refer to the publisher's version if you intend to cite from the work. See Guidance on citing.

To link to this article DOI: http://dx.doi.org/10.1080/00076791.2017.1323883

Publisher: Taylor \& Francis

All outputs in CentAUR are protected by Intellectual Property Rights law, including copyright law. Copyright and IPR is retained by the creators or other copyright holders. Terms and conditions for use of this material are defined in the End User Agreement.

www.reading.ac.uk/centaur 
Central Archive at the University of Reading

Reading's research outputs online 
How far does the apple fall from the tree? The size of English bank branch networks in the nineteenth century

Victoria Barnes (Max Planck Institute for European Legal History) and Lucy Newton (Henley Business School, University of Reading)

Biographical notes:

Victoria Barnes is a Researcher at the Max Planck Institute for European Legal History, Frankfurt am Main, Germany.

Lucy Newton is an Associate Professor at Henley Business School, University of Reading, UK.

Corresponding author's email address: 1.a.newton@henley.ac.uk 


\title{
How far does the apple fall from the tree? The size of English bank branch networks in the nineteenth century
}

\author{
After the Bank Charter Act in 1833, English banks could branch nationally without legal \\ or geographical restriction. It has been previously thought that despite this freedom, early \\ English joint-stock banks predominantly began as single units. Drawing upon a new \\ dataset, this article maps the growth of branch banking, the size of bank networks and \\ their geographical location and spread. It demonstrates that banks pursued branching \\ strategies energetically against the intentions of regulators and were successful in forming \\ large and complex networks. However, ultimately, before 1880 the majority settled for \\ local, district and multi-regional structures, as opposed to national structures.
}

Keywords: banks, branching, branches, regulation, strategy.

\section{Introduction}

Expanding out into new areas and territories is a strategy that is commonly used by businesses as a way to increase their revenues. The decision to enter into a new market is usually considered in an international or global context. As Jones has noted in his seminal study of the evolution of multinational firms, British banks were pioneers in expanding their businesses as they were undeterred by the difficulties and risks associated with crossing borders and managing branches that were far flung from the head office of the bank. Engaging energetically in the first wave of globalisation, British banks introduced banking to the colonies of Australia, Canada and the West Indies early in the nineteenth century. ${ }^{1}$ The overseas agenda of British banks has been characterised 
in the business history literature as ambitious, entrepreneurial and flexible. ${ }^{2}$ However, the policy of domestic banks has the opposite reputation and for different reasons. At home, British banks have not been judged upon their own internal performance but upon their willingness to lend and support industrial growth. ${ }^{3}$ The British financial sector has been accused of failing to provide adequate amounts of capital to British industry in the nineteenth century as it saw these transactions as too risky. ${ }^{4}$ British banks have also been viewed as cautious with regard to their propensity to branch before the 1880s and the merger movement, again due to the inherent risk involved. ${ }^{5}$ British banking has thus been seen as embodying conservative cultural values, resulting in a failure to fully seize opportunities to increase revenue. ${ }^{6}$

This article breathes new life into an old debate about the character of the British banking. It focuses upon appetite for change and growth by examining the expansion of banks in the domestic rather than overseas market. We employ the concepts and frameworks that have been more commonly used in the literature on multinational banks to examine the entrepreneurial nature of British banks and their branching strategies. $^{7}$

As well as permitting entrepreneurial expansion, the ability to conduct branching is also considered to be a central factor which contributes to bank stability. ${ }^{8}$ Maintaining a network nationally or across regions allows banks to diversify their risk and increase profitability. Banks utilise their resources efficiently by moving money from areas where deposits are plentiful to other regions where demand for lending or opportunities for investments are greater. Yet branching is not without risk $^{9}$ : it may improve access to deposits and better liquidity but this can loosen control and even impair the bank's 
ability to gather local knowledge and soft information. Thus banks had to manage expansion via branching effectively in order to avoid undue risks and potential losses.

Regulation has often been seen as the principal force that has prevented the establishment of large branch networks, in the United States in particular, as several states forbidding branching or establishing geographical limits on expansion. ${ }^{10}$ Britain in the nineteenth century, by contrast, was largely free from such restrictive legislation. Following the crisis of 1825/6, the Banking Co-partnership Act 1826 permitted the formation of joint-stock banks. After 1833, legal restrictions in England and Wales were lifted, removing limitations on the scope of geographical operation of banking and branching. While there was no outright prohibition of branching, a series of reforms was passed thereafter which presented new obstacles in an indirect and subtle attempt to prevent and discourage such activities. From 1833 onwards, English banks could, in theory, legitimately follow any number of branching strategies and banks were permitted to operate across the nation. This research sheds light on the branching strategies that these banks decided to take, given that they operated with relative legal freedom to enter into such agreements but, at the same time, experienced political pressure to desist from ambitious planning and expansion.

This article investigates the branching strategy of banks in England and Wales; their enthusiasm in creating large national networks capable of spreading risk geographically, as well as the dynamism and willingness to explore and service new areas. In doing so, it provides a unique insight into the ambition and strategy of the new joint stock banks and presents these institutions as able to take risks. These were not, as has previously been portrayed, timid or inherently conservative organisations. Given legislative freedom from 1826, the early joint stock banks looked to expand their 
business and provide services for a growing customer base. Such branching activity was not, as has previously been portrayed, the preserve of joint stock banks operating after 1880 ,

Using a new dataset of branch networks, this article asks: did banks pursue flexible and ambitious branching strategies or did they act conservatively only forming small-scale single unit banks? What kind of networks - in terms of shape or size - did banks create? Did they create large branch networks of national proportions capable of diversifying risk geographically? The first section begins by providing an overview of the development of branch banking and traditional explanations for the levels of branching in the nineteenth century. The second then examines the dataset and discusses its key findings. The results from the dataset are analysed in terms of branch numbers and then we turn to the issue of locations and the size and shape of branch networks. Following this, the article then considers explanations for these trends; particularly the regulatory context for branch banking. Finally, we examine Manchester and Liverpool District Bank as a case study to further explore branch strategy.

\section{What was a branch and why were they important?}

The ability to branch is important to banks to enable them to expand their business and to reach new customers, both depositors and borrowers. Growth through branching is a quick and cost efficient way of gaining market share; business expansion; and diversifying deposit base, shareholder base and borrowing customer base.

What is a branch? Under English regulation, branches have been defined loosely throughout history. This definition would constitute offices and places of establishment, so, therefore, include branches, sub-branches and agencies. In practice, the difference 
between the three was quite considerable. A branch was overlooked by the head office. A sub-branch reported to the branch. ${ }^{11}$ An agent, not usually an employee or subject to those sanctions or level of control, would instead act with some independence and enter into contracts with third parties on the bank's behalf. ${ }^{12}$ An office, on the other hand, comprised all three of these different types of businesses. It was simply a building in which the practice of banking took place. Other differences could include opening hours (for example only opening one day a week on market days) and premises, both of which could be quite considerable in terms of costs. Nevertheless, the type of business which took place at these locations, if not the volume, was largely the same. The diversity in the scale of branch operations persisted through the nineteenth century and into the early twentieth century. ${ }^{13}$

In the nineteenth century, branching was not only important for growth but also to spread the risks inherent in lending to local economies alone. By extending a bank's spread geographically through branches, their customer base was also expanded, and thus the bank would be less dependent upon one area or region and the industry and commerce therein. Local banks, even with branches, tended to lend to one sector and such specialisation led to increased risk for the bank. ${ }^{14}$ Broader geographical expansion could reduce this risk. Branching also expanded a bank's depositor base (the main source of funds above investment from shareholders), providing a more stable capital base. With this in mind, more deposits also provided lendable resources for the bank and thus increased the opportunity to profit from extending credit (with charges) to customers. Extra-regional branching thus provided a new opportunity for greater profits and the potential ability to absorb regional shocks. 
Legislation had permitted the establishment of joint-stock banks in 1826 in order to encourage a more stable banking system. The ability to branch was available to all joint-stock banks from 1833 onwards, into the twentieth century, and added to the stability of many of these institutions. Yet during the nineteenth century, in an era where transport and communications were limited, there were also risks inherent in delegating authority to branch managers and in lending outside the sphere of knowledge of the bank's head office and its directors. If a bank extended business too far and did not maintain control of advances made via branches distant from its head office, and to customers about which they had little direct knowledge, then poor lending decisions could be made and losses and instability could ensue. To reduce the risks involved in delegating authority to branches, it was essential that they were run efficiently and did not undertake lending that was excessively risky. Thus, bank head offices had to be able to control the activities of their branches through monitoring but also through delegating authority to their managers with confidence. This necessitated the appointment of both capable and trustworthy managers.

Adam Smith was concerned with the risk taking that was potentially involved in the separation of ownership and control involved in joint-stock companies, whereby the principal (shareholders) delegated management authority to directors and managers (agents). He was concerned that those delegated to manage a company would never be as conscientious in their care of the money of others as they would of their own funds. ${ }^{15}$ The banks formed after 1826 had joint-stock status but not limited liability (which was not permitted until 1858). Yet the ability to appoint and trust managers to run branches connected to the concerns of Smith. How could bank shareholders and directors be sure 
that a manager appointed to run a company would do so in a reliable, trustworthy and successful manner?

When considering industrial units in the twentieth century, Heim asserted that managing a network of distant branches 'requires a degree of organizational sophistication' and certain technology to enable processes to manage branches. ${ }^{16}$ Insurance companies, such as the Prudential, successfully developed a national branch system to sell their policies. ${ }^{17}$ The 'industrial' branch system worked well as it was operated by agents who sold insurance policies directly to the consumer and consequently collected the premiums to pay for these policies. In this system there was an incentive for the agent to operate in an honest manner in order to 'stay on good terms with their customers since they were an important source of repeat business and new leads', in other words their incentive was to generate business and thus get paid. ${ }^{18}$ Thus, extensive branching in financial services operated successfully in insurance. Branching also took place in the retail sector in the nineteenth century from the 1850 s onwards, with the trend for multiple shop retailing increasing from the 1870 s, culminating in a few retailers possessing very large branch networks by $1914 .{ }^{19}$ Jefferys attributed this expansion in retail branching to being able to spot opportunities for expansion, the mastery of the organization of multiple units and the availability of capital. But he acknowledged that 'expansion from a local or regional market to a national market proved more difficult' due to capital requirements and the logistics involved in the national distribution of goods. ${ }^{20}$ Despite such problems, retailers had an incentive to branch due to the benefits that economies of scale could bring, in particular, lower operating costs and also the ability to purchase large volumes of goods at lower prices. ${ }^{21}$ 
The late nineteenth and early twentieth century has also been seen as the period for peak branching for banking in Britain. Yet, some early joint-stock banks ventured forward and branched, presumably making the assessment that any potential risk was worth the potential gain but these were previously considered to be rare. ${ }^{22}$ Noting that many banks began as single units, English bankers seemed to become fonder of branching as the nineteenth century progressed. ${ }^{23} \mathrm{~A}$ number of explanations have been proferred to explain why joint-stock bankers were reluctant branchers before 1880 . First, these banks were thought to operate in a similar fashion to their private counterparts - expanding geographically and delegating authority to a variety of individuals was a level of risk that most private bankers were either unwilling or unable to take. ${ }^{24}$ In this system, information and knowledge, essential to bank stability and lending decisions, was exchanged and created by bankers who knew their customers and applicants. For example, Hudson observed in the 1830s and 1840s that 'banks with branches in the West Riding ..... failed... partly it seems because remoteness from [the] head office meant that it was more difficult for branches correctly to assess the creditworthiness of parties applying for loans' ${ }^{25}$ In the American case, Lamoreaux suggested that 'specialization undoubtedly helped bankers reduce their vulnerability to failure'. ${ }^{26}$ Branch banking can be seen as a risky strategy due to the problems associated with distance and communication.

Second, while bankers possessed knowledge about their customers, it is also thought that they lacked the systems of control and those trained in accountancy to monitor a large branch networks. Sayers noted that shortly after Lloyds first became a joint-stock bank in 1865, no one 'from the Managing Director down to junior clerks... had the slightest idea how to work the new ledgers... or how to start or carry on proper 
entries' ${ }^{27}$ Without basic information-recording procedures or staff to carry them out, Baker and Collins commented that coordination and 'the concept of central control still remained something of a rarity! ${ }^{28}$ Joint-stock banks could gain knowledge and experience by poaching more experienced staff from Ireland and Scotland ${ }^{29}$ where branching banking had taken place earlier and more extensively. ${ }^{30}$ For the most part, this problem was thought to be solved gradually as banks became well established and so could train and recruit their own staff from the lower ranks of their companies. ${ }^{31} \mathrm{It}$ followed that with more opportunity to develop internal administrative processes and train their managerial staff, stronger mechanisms and standardised systems of control were instituted. In such an environment, banks could then engage in large-scale branching successfully. The transformation in accounting procedures and the professionalization of bank staff was tied to the development of branching habits and the change dated to the last quarter of the nineteenth century with the foundation the Institute for Bankers. The Institute was created in 1879 to produce better quality managers and to impose standards on the profession of banking. ${ }^{32}$ Thereafter, changes took place which saw a few large banks, with head offices based in London overlooking extensive branch networks. ${ }^{33}$ The 'Big five' banks that dominated the banking sector in 1918 achieved their size by acquiring smaller banks through mergers and expanding their branch network. It was an efficient way of expanding geographically while at the same time reducing risk and uncertainty through gaining existing expertise and local knowledge. ${ }^{34}$ To summarise, previous literature has asserted that, while from 1833, joint-stock banks had no limits in their ability to branch in terms of regulation, before the 1880 s they were hindered by what was thought to be a lack of experience in 
branching and relatively poor training. The following section will consider the dataset and the number of banks and of their branches.

\section{Network size}

This section considers the number of banks and their branches, gathered from the dataset, before turning to locations of branches in the following section. The dataset shows several key developments in branch banking in this period; most notably the rise of banks with large branch networks and also the persistent but declining strength of single unit banks in England and Wales. Most significantly, this section provides evidence that joint-stock banks possessed extensive branch networks.

The dataset used here has been constructed from a multitude of sources such as, Parliamentary Papers and Fenn's Compendium, and after 1844, the Banking Almanac has been used. The Stamp Act 1815, required that banks send information which documented all the places and locations in which the bank and/or its branches existed to the Stamp and Tax Office. This information was published in two ways. First, those writing trade directories would gather this information from the Stamp and Taxes Office so that individuals would be able to identify locations to use banking services or transfer money. As such, directories would often detail the locations of all banks, both private and joint-stock. Second, in the absence of more stringent controls on disclosure of information, Parliament gathered and published this information on a near annual basis. This reflected its concern about the nature, scale and scope of joint-stock banking.

Contemporaries questioned the accuracy of the branch data. Waterson, a compiler of statistical information, considered that 'it is a common practice of the banks to insert in their licenses places where circumstances may induce them to establish 
branches, but where none were in existence at the time the license was granted' ${ }^{35}$ In other words, banks would say that they operated in a location that they did not as yet, in order to fend off competition. The result of this practice could mean that the number of branches would be far greater than those actually established.

Without a rival dataset, it would perhaps be difficult to find evidence that falsification was widespread or the norm. Yet, more to the point, Joplin, a director in the National Provincial Bank of England and another joint-stock bank in Ireland, considered that 'there can be no motive for making such a return, and I cannot imagine a single false return was ever intentionally made, though the mode of registration may no doubt be improved'. ${ }^{36}$ Thus, he saw nothing to be gained by falsifying returns. It is also important to remember that this information had a contemporary use and purpose: to establish the presence of banks and other financial institutions so that individuals could transfer money across the nation. A clear and predictable result of listing a false branch in a location that did not exist would be embarrassment, loss of custom and a certain degree of reputational damage.

In order to combat the problem of inaccuracy, we have carried out a number of checks on the data and used anecdotal evidence from other sources to confirm their validity. Indeed, the sources used here caused some issues/problems. For instance, while all banks were required to submit this information, they did not follow a consistent way to list their offices. Basic problems and errors existed, such as inaccurate computation of the number of branches. One example involves the coding of place names. National Provincial Bank of England branched in 'Newcastle Emlyn' in west Wales but National Provincial Bank of England (or the Stamp Office) entered this location as two places and branches: 'Newcastle' and 'Emlyn'. Following further investigation with local trade 
directories, after finding out that 'Emlyn' did not exist, it transpired that National Provincial Bank of England did not branch in the city or town of 'Newcastle' (neither Newcastle upon Tyne in Northumberland or Newcastle under Lyme in Staffordshire) but actually it branched within 'Newcastle Emlyn'. In other examples, banks gave the county name as well as the name of the city, town or village. While such an act could be perceived as deliberate attempt to exaggerate the extent of the firm's coverage, a county name tended to be a useful way of giving the user clarity. A county name was generally used in the contexts where there the branch could be in a variety of locations because the city, town or village name was especially common.

Table 1: The size of the branch networks

\begin{tabular}{|l|r|r|r|r|r|r|r|}
\hline & 1830 & 1836 & 1844 & 1854 & 1864 & 1874 & 1877 \\
\hline All banks & & & & & & & \\
\hline Mean & 5 & 8 & 6 & 6 & 8 & 10 & 12 \\
\hline Median & 1 & 3 & 2 & 2 & 3 & 4 & 5 \\
\hline $\begin{array}{l}\text { Standard } \\
\text { Deviation }\end{array}$ & 6 & 10 & 11 & 13 & 19 & 20 & 22 \\
\hline Maximum & 25 & 42 & 93 & 99 & 162 & 149 & 153 \\
\hline Minimum & 1 & 1 & 1 & 1 & 1 & 1 & 1 \\
\hline Number & 16 & 63 & 105 & 98 & 109 & 120 & 119 \\
\hline & & & & & & & \\
\hline $\begin{array}{l}\text { Five Largest } \\
\text { banks }\end{array}$ & & & & & & & \\
\hline Mean & 12 & 34 & 41 & 49 & 75 & 86 & 94 \\
\hline Median & 10 & 40 & 27 & 26 & 33 & 50 & 72 \\
\hline $\begin{array}{l}\text { Standard } \\
\text { Deviation }\end{array}$ & 7 & 9 & 26 & 32 & 56 & 47 & 44 \\
\hline Maximum & 25 & 23 & 93 & 99 & 162 & 149 & 153 \\
\hline Minimum & 4 & 42 & 23 & 20 & 27 & 46 & 52 \\
\hline
\end{tabular}

Source: Dataset 
Figure 1: The number of bank offices in England and Wales, 1827-1877

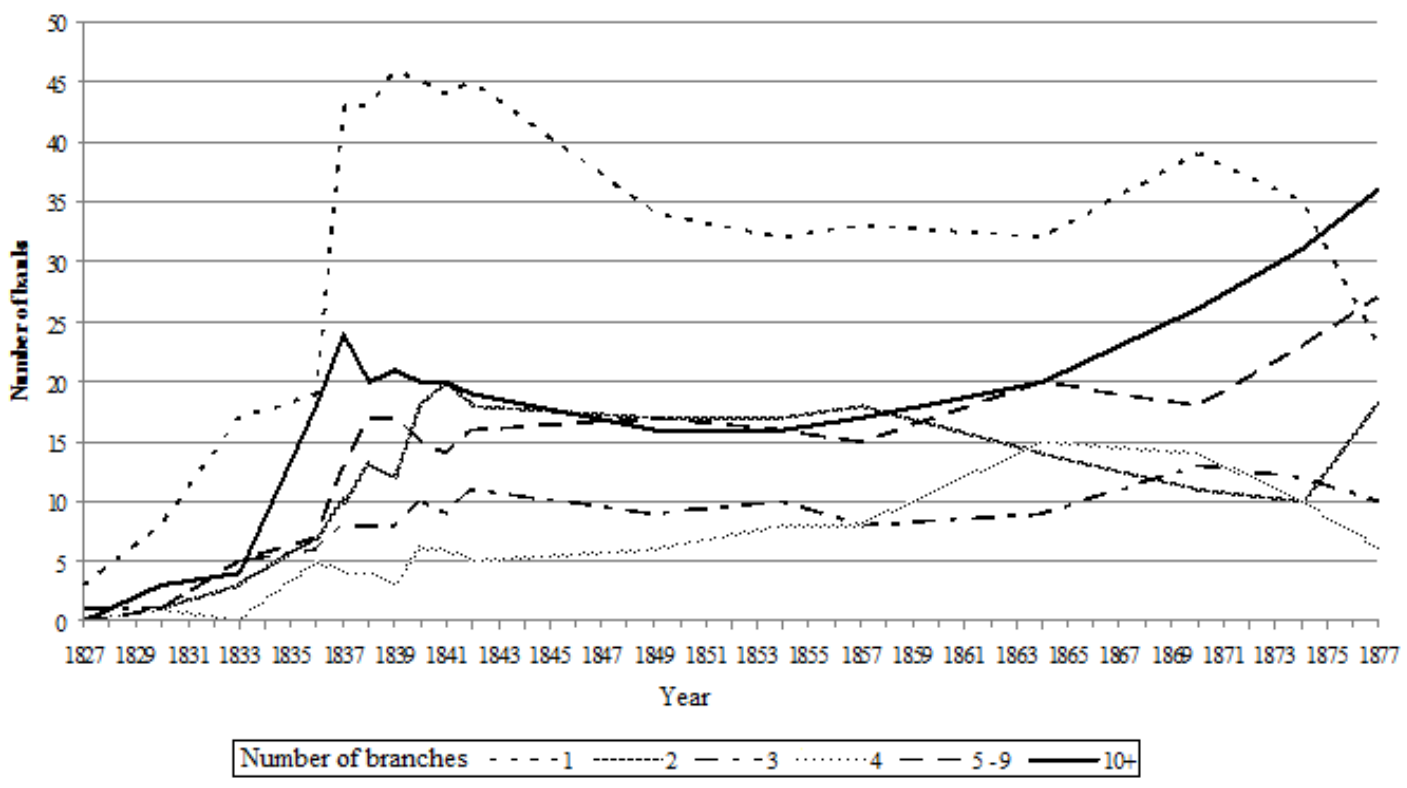

Source: Dataset

Having addressed the construction of the dataset, Table 1 demonstrates that the key rise in branches was in 1836 and from the 1860s onwards. It shows that whilst the mean number of offices per bank rose from 5 in 1830 to only 12 in 1877 , the five largest banks in the sample show that the more vigorous branch banks expanded their networks. They did so in a linear fashion and far more prodigiously than the 'norm', reaching an average of 94 branches by 1877 . Figure 1 organises the number of branches that they possessed (from unit banks to those with 2, 3 or 4 branches, 5 to 9 branches or with 10 or more branches) in order to contrast banks with branch networks to those with a few branches and those single unit banks. While National Provincial's branch network has been traditionally recognised as being atypically large,,${ }^{37}$ this dataset shows that numerous other banks also managed a complex network of branches, if not on quite the same scale as the National Provincial, contradicting previous assertions that the early joint stock banks were reluctant branchers. 
Figure 1 shows that English and Welsh joint-stock banks branched vigorously. Although the majority of joint-stock banks in operation between 1826 and 1877 were single unit banks, a significant proportion had relatively large branch networks - that is from 10 to 162 branches. In particular, those branching in and before 1836, when jointstock banking was in its infancy, had traditionally been viewed as being predominantly small, unit banks yet the dataset demonstrates otherwise. For example, Stuckey's Bank, formed after the passage of the 1826 Act as a merger of private banks, possessed 9 offices in 1827. The Wilts and Dorset Bank and West of England and South Wales District Bank began trading in 1836 with branches in 42 and 20 locations respectively. ${ }^{38}$ Regional branch banking was not confined to the South West of England as the North and South Wales Bank (established in 1836) almost doubled the size of its branch network in its first year of operation with a rise from 22 to 41 offices. ${ }^{39}$ Such expansion was not always anticipated. For instance, the Plymouth and Devonport Banking Company renamed itself the Devon and Cornwall Banking Company in 1833 'in consequence of its having extended its branches beyond the limits originally contemplated' ${ }^{40}$ Overall, Figure 1 identifies that in 1836 the number of banks with large branch networks (those in the category of 10 or more branches) almost equalled single-units banks.

After 1836 branch networks generally regressed towards the smaller or single unit model. Following the failure of the Northern and Central Bank in 1836, Parliament inquired as to the circumstances of its collapse and several witnesses blamed its failure on large branch networks and the quality of the management of both the bank and its branches. ${ }^{41}$ This had an important set of consequences. Several banks, including the Ashton, Stalybridge, Hyde and Glossop Bank, abandoned their plans to branch. ${ }^{42}$ Some, 
for example the Manchester and Liverpool District Bank, were able to buck the trend and maintained a network of 23 offices. Contraction, coupled with an increase in number of newly formed single-unit banks, meant that the average number of offices per bank fell to more modest levels (see Table 1 and Figure 1). In 1836, joint-stock banks had an average of almost 8 offices per bank, demonstrating that branching in the early phase of their development was marked. With gradual expansion thereafter, as Table 1 shows, the average branch network in England and Wales was not this size again until the mid-1860s.

Therefore, some banks in our sample undertook ambitious branching strategies before 1836. After a hiatus in branching activity from 1836-1857, several banks - those with the largest branch networks in our sample - undertook aggressive branching strategies in the early 1860s, as shown in Table 1 and Figure 1 . This branching was at a regional level but the example of the National Provincial Bank of England attests to the ability of an English bank to run a large, multi-regional branch network successfully during this period.

National Provincial, originally established in 1833, started out and remained an ambitious brancher. It was the bank with the greatest number of branches in 1844. By 1877, National Provincial was 'out branched' (in terms of numbers of branches) only by the London and County Banking Company, established in 1836. Between 1854 and 1877, the London and County Banking Company had begun a policy of rapid expansion, almost doubling the size of its network from 57 branches to 153 . National Provincial likewise enlarged its network but by 1877 it was marginally smaller with 143 branches. The remaining large branch banks also followed a strategy of geographical 
expansion but their branch networks remained smaller than either National Provincial and London and County Banking Company.

Thus the dataset shows that there were several banks with substantial networks throughout this period. Although the majority of the first wave of joint-stock banks in England and Wales constituted single unit banks, a significant number also engaged in branching and a significant number formed complex and extensive branch networks. The next major upheaval in the structure of banking in the UK occurred in the amalgamation movement of the 1880s and 1890s. This evidence contradicts the view that joint-stock banks were reluctant branchers prior to the merger movement of the 1880 s and 1890 s, as has previously been asserted.

\section{Network shape}

Thus from the very outset, joint-stock banks conducted extensive branch operations. As they became more established, and had a propensity to branch more than their private counterparts, their networks spread to extend to areas not well served by private banks. Gilbart, the manager of London \& Westminster joint-stock bank, explained that a jointstock 'branch bank may thus be established in a place where a private bank could not exist' ${ }^{43}$ In such cases, it would be affordable and profitable to establish a branch but not a whole bank. Despite the advantages of branch banking, this section finds that all banks tended to follow a regional rather than a truly national branch strategy.

Branching locally was an intrinsic part of the joint-stock format and its ability to gain more custom through this strategy ensured that a joint-stock bank could survive competition with their private counterparts. Indeed, branching to improve local levels of community service was a key part of the strategy of the first wave of joint-stock 
bankers' strategy, and they aimed to service nearby communities efficiently with banking provision, especially after the financial losses experienced in the $1825 / 6$ crisis. For example, the Huddersfield Bank prospectus, declared that private bank failures: 'have been the means of again retarding the growing prosperity of a district which in former years had to encounter similar evils. By the failure of these banks a vacuum has been caused which, in all probability, will be filled up by other establishments of a similar nature; equally subject to the same disasters and from which the same consequences may again arise; unless a public company of a more solid description be formed in their place'. ${ }^{44}$ Indeed, the data in Figure 2 shows that banks with large branch networks displayed a distinctly regional focus and rarely served multiple commercial centres. For instance, Manchester and Liverpool District Bank rather unsurprising located itself in the north west. It opened a branch as far as Bangor in the 1830s but soon abandoned it. London and County, the bank with the highest number of branches at the end of our dataset in 1877, did not expand that far outside of the south east. While failure to branch at a distance may be seen as a sign of lack of ambition and indeed conservatism, there was a fine line between ambition and naivety.

If strong systems of governance or control of branches were not enacted, the bank could be exposed to risk or poor performance. Poor procedures and processes for information recording could be developed over time and these were learned competencies. Through experimentation and experience, supervision could be improved, but the immediate risk could be fatal. There were also heightened hazards involved in lending to industries that were outside the immediate area of expertise of bank directors and managers. Such dangers would usually be reduced at a local level 
through knowledge about customers and the sectors in which they operated gathered through local networks or via personal relationships with customers. Branching outside a local hinterland obscured such local advantages. Over-extension and excessive branching could also, potentially, lead to less responsible banking and of course costs would be incurred, for example costs to the bank of communicating with and monitoring branches.

The National Provincial Bank of England came closest to a national coverage by 1877 but, as Figure 2 shows, its geographical spread was patchy and incomplete; it performed as a multi-regional bank rather than a truly national bank. It expanded aggressively over time and developed a wide network. It noticeably did not branch extensively in either the north west or in Yorkshire, but it branched more extensively in areas where joint-stock banking services were less prominent, such as the south west of England and in Wales. Moreover, its branching in London did not take place in the first half of the nineteenth century, but rather 1857. It was, as its name suggests, a provincial bank. ${ }^{45}$ Therefore it operated in many ways like a series of connected district or regional banks. Even so, National Provincial illustrates that the problems of weak control and distance could be overcome.

With the introduction of limited liability in 1857 , banks changed their strategy and the impact of the legislation on branching was two fold. First, it provided opportunity for a new wave of bank promotions and these formed with a distinct and different shaped network, as shown in Figure 3. In the 1860s, the country was becoming a crowded market for banks and they serviced all major cities and commercial areas. ${ }^{46}$ Yet, with a prosperous economy, bankers took advantage of the strategy of expansion into two or more cities, demonstrating the competitive environment for banking but also 
the space for competition in the market. ${ }^{47} \mathrm{New}$ banks, instead of prolific branching at a regional or district level, had a smaller number of branches but a set of complex geographical profiles. These banks expanded the most in terms of distance from their head office but their network was leaner and more focussed than previous branching strategy. The post-limited liability banks centred upon hubs of industry and targeted cities with high levels of commercial activity rather than entire regions. Many new entrants founded after limited liability were governed by a London head office with a multi-regional branch network, for example London and Provincial (formerly known as Provincial Banking Company), ${ }^{48}$ London and South Western, London and Northern and London Bank of Scotland. ${ }^{49}$ Looking out from London, these banks possessed a 'London plus' network. This activity existed in sharp contrast to those joint-stock banks that established in London in the 1830s and 1840s. The latter banks did not initially create wide branch networks that spanned to distant and major hubs. Yet, such activity had occurred by the end of the dataset in 1877 , with the new 'London plus' strategy adopted after the introduction of limited liability.

A second feature of bank strategy after 1857 was the renewed expansion of the existing banks as a response to the threat of new competition. These new banks tended to compete and overlap several territories held by existing joint-stock competitors. In 1885, Rae explained the strategy of the banks formed before limited liability and the motivations behind reactive expansion:

If on the line of towns A., B., and C. you have Branches at A. and C. only, you could not allow another bank to occupy B. You would have to do so yourselves, although you might have to work the Branch at a loss'. 50 
Existing banks thus expanded and used branches as a shield to protect territorial advantage and to prohibit the establishment of new banks. ${ }^{51}$ This expansion was therefore local and banks did not expand extra-regionally or at a distance.

The refusal to adopt a national system had prompted Gilbart to comment in 1836, that the English branching system was a 'district' system and 'analogous' to the one in the United States. He considered that 'American banks do not extend their branches into neighbouring states'. ${ }^{52}$ The post-limited liability London-plus banks had expanded outward. Yet they still did not take the opportunity to operate on a national level. Neither did the first wave of banks formed before 1857, which were regional or district entities. Indeed, not much appeared to have changed in terms of their network shape.

Overall, even though English regulation permitted banks to establish national banking structures, the networks with the largest number of branches tended, like American banks, to be concentrated or locked within regions. These district banks formed in the first phase of joint-stock banking (1826-1857). Some banks, especially those formed after limited liability, maintained London-plus networks. With smaller but more focussed multi-city networks, the post limited liability banks sought to cover several hubs of commercial activity. National Provincial Bank of England came closest to forming a national network but even so, it failed to achieve consistent or truly national coverage. Instead, it appeared as a multi-regional bank. Having examined in details patterns of bank branching, the next section considers the regulatory context in which this branch activity took place. 
Figure 2: The distribution of all branch locations for National Provincial, London and County and Manchester and Liverpool District Bank

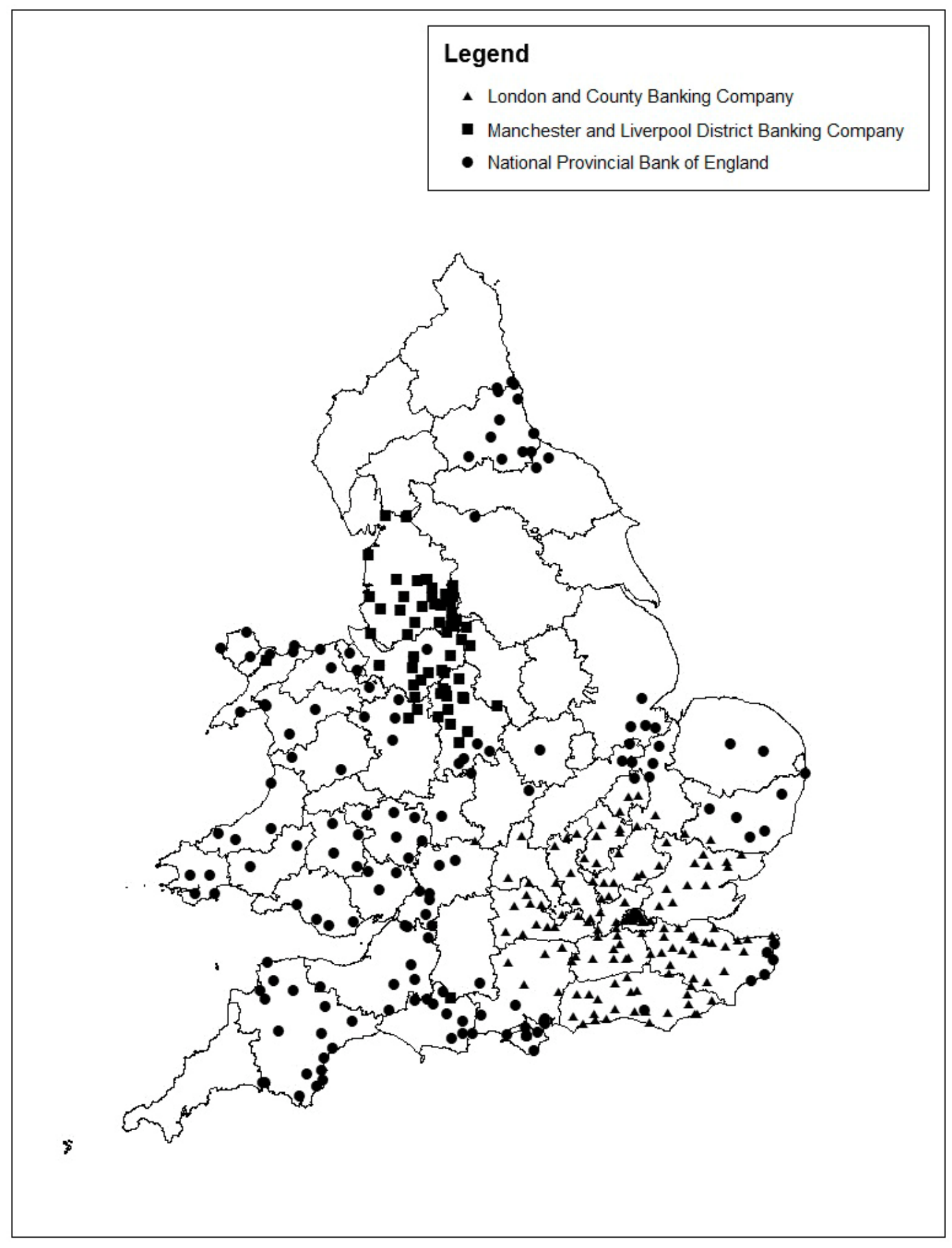


Figure 3: The distribution of all branch locations for London and Provincial Bank Limited, London and South Western Limited and London and Yorkshire Bank Limited.

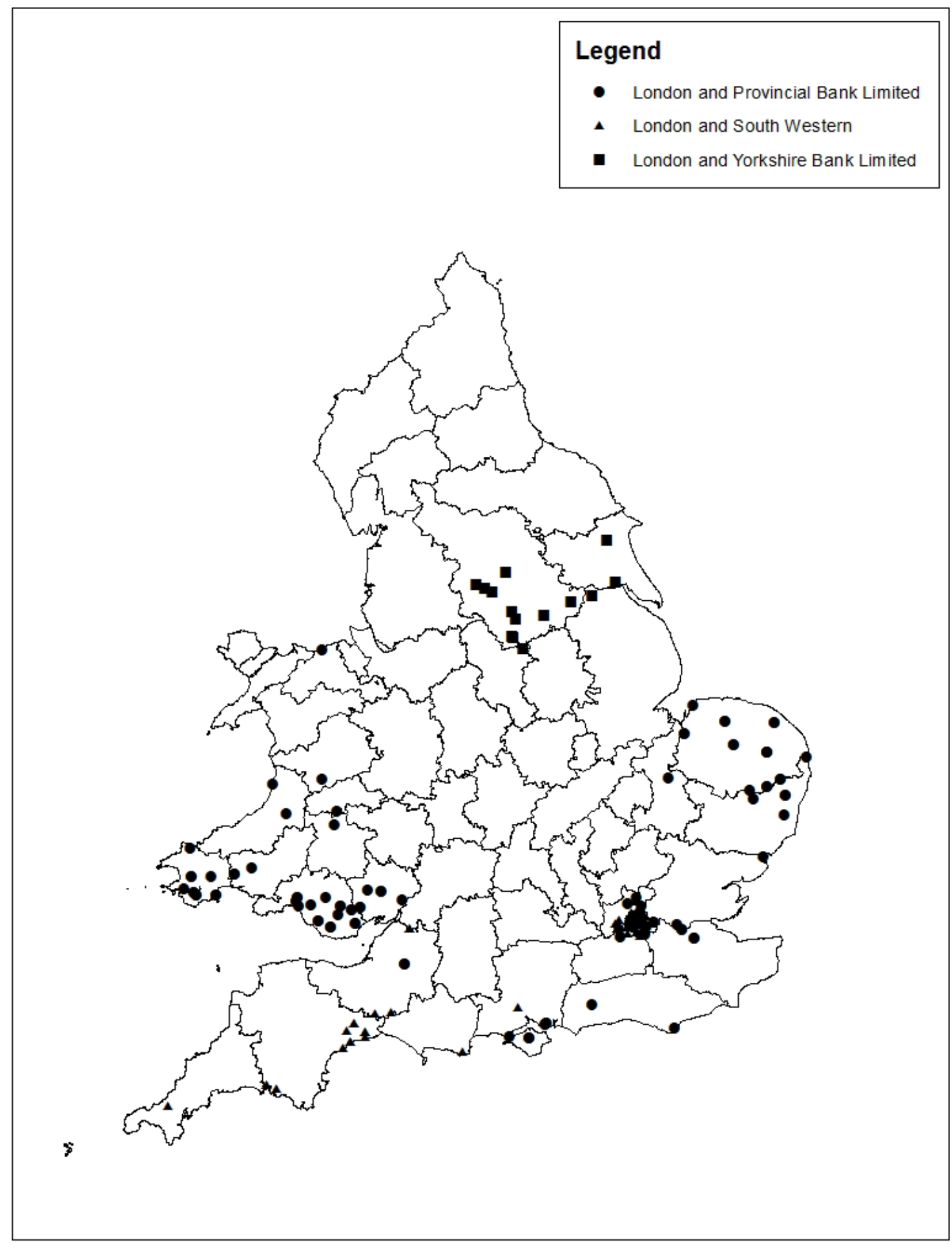




\section{Regulatory context}

Across the nineteenth century, reforms aimed explicitly to contract the size of the banks or their branch networks in England and Wales. The branching that took place was thus in spite of these regulatory concerns. Moreover, several of the peaks and troughs in the numbers of branches can be explained by the changing nature and influence of regulation, together with the growing political and social dislike for branch banking. This section examines legislation that permitted (or restricted) the development of jointstock banking companies as new financial institutions and permitted an entirely different model of banking - one that developed a branch network - in comparison to their private counterparts.

Before 1826, the Bank of England held a monopoly on the practice of jointstock banking and prevented more than six partners from creating a bank. Following the crisis in $1825 / 6$, emergency legislation intervened to improve the stability of the English banking system. The Banking Co-partnership Act 1826 altered the Bank of England's monopoly in order to remove the six-partner restriction and thus introduce joint-stock banks. It encouraged new banks to operate like partnerships and private banks that did not branch. These new banks would have an unlimited number of owners, in comparison to the private banks which were limited to just six partners. Joint-stock banks were permitted to form outside of a 65 -mile radius of London. ${ }^{53}$ The Bank of England defended its exclusion zone vigorously through litigation, but more often mere legal threats were sufficient to see off those trying to establish within the 65-mile exclusion zone. ${ }^{54}$

In terms of branching, the wave of new banking legislation did not alter the regulation of the size of branch networks. Indeed, the Stamp Act 1815 remained in 
place. It required that banks had to apply for a licence for every branch, which cost $£ 30$ each, but an out-dated clause stated the maximum number of licences required was four. In practice, this meant that a bank with 50 branches needed only four licences. ${ }^{55}$ As Parliamentary inquiries clarified that the law did not limit the number of branches in 1833, and again in 1836, so joint-stock banks followed the letter of the law. ${ }^{56}$ They did not apply for more than four licences, even if the bank had more than four branches. In contrast, private banks (that did not branch and the basis upon which the legislation was founded) rarely tested or pushed through this threshold whereas joint-stock banks did. ${ }^{57}$

The Bank Charter Act of 1833 reaffirmed the Bank of England's monopoly and, by extension, the rights of other bankers. The Act of 1833 confirmed that joint-stock banks were now permitted to establish in London, within the 65-mile exclusion zone, but that they would not have note-issuing rights. ${ }^{58}$ Joint-stock bankers had pushed the legal boundaries to ensure that they could establish a branch network of national proportions, one that extended across the whole of England and Wales, including London, without geographical restriction. As this rule already existed in common law, the Bank of England and Parliament felt obliged to keep it and maintain the legal position.

Parliamentary inquiries in 1836, 1837, 1838 reflected a residual nervousness about branch banking, an anxiety which had developed in the 1820 s when joint-stock banks began branching (unexpectedly in the eyes of the legislators - see below), and which led to a strong push in Parliament for new legislation to curb branching activity, and to restrict joint-stock banks more generally. Anxiety was expressed in relation to unnecessary branches and potential resultant instability. ${ }^{59}$ After a period of intense political scrutiny in the 1820 s and 1830 s, and following the high profile failure of 
Northern and Central Bank in particular in 1836 - a bank with a large branch network Parliament finally achieved their aim with legislation in $1844 .^{60}$

The 1844 Bank Charter Act was a reaction to the unforeseen action by those joint-stock banks established after the 1826 Bank Act. These banks could be formed with relatively minimal effort and, as the cost of licences to establish branches were nominal, early banking legislation did very little to dis-incentivise branch expansion. As branch banking was not inherently connected to the existing model of private banking, legislators did not understand the risks associated with it nor did they predict the changes that were to come. With the Scottish model in mind, bankers in England exploited this misunderstanding and branched. The attitude towards branching in parliament changed with the failure of Northern and Central in 1836, and the law restricting joint-stock bank formation followed in 1844 .

The 1844 legislation acted to curb further growth in banking in two ways. Firstly it did so in order to prevent the promotion of new banks. Peel, the bill's promoter, ensured that any new joint-stock bank could only be established by letters of patent or by royal charter and a large amount of capital. The 1844 Act thus discouraged new bank formation and promoted a return to charter based incorporations with new restrictive capital requirements. New joint-stock banks were required to have a minimal capital of $£ 100,000$ and share denomination of $£ 100$.

Secondly, the new legislation discouraged the development and maintenance of large branch networks. Peel doubted 'whether these banks having 50 or 60 branches in very small towns renting houses and appointing efficient persons to superintend them is a wise policy ${ }^{61}$ With this in mind, the 1844 Acts acted to inhibit mergers and amalgamations (often a way to form branch networks) by restricting the use of financial 
instruments. The Act achieved this by limiting each bank's note issue to the amount in circulation in 1844 , a measure also used to hinder movement within the banking system. The new rules would mean that only the Bank of England could increase its own note issuing. Thus if a private bank joined with another bank to form a joint-stock bank after 1844 , it could not combine note issue. Similarly, joint-stock banks could not merge and retain both issues. As joint-stock banks and private banks tended to be banks of issue, it was intended to deter amalgamations between banks. And if a bank was a new promotion it could not issue notes at all, adding to the disincentive to new formations.

The Act also closed the legal loophole that required banks to only purchase four licences costing $£ 30$ each (irrespective of the size of the network). Under the 1844 Act, banks had to have a licence for every single branch in their network. Although the cost of the licence had not changed and remained at $£ 30$, the new requirement to take out a licence for every branch would deter the retention of old branches which were unprofitable, but also discourage the opening of new branches.

The policy of 1844 aimed explicitly to restrict further growth of joint-stock banking and to reduce the size of a large branch networks. Indeed, it was successful in the former but not the latter. It halted new promotions as only 12 new joint-stock banks were formed between 1844 and 1857 (when the legislation was repealed), ${ }^{62}$ and banks did not restart or conduct a strategy of expansion. However, during this period, banks did not follow Peel's instructions and downsize their networks. Some banks had already reduced the size of their networks in 1836 but there was no further decline in the size of the branch network under the 1844 legislation.

The introduction of general corporate limited liability in 1855 was seen by some legislators as a means to improve management of firms rather than encourage growth or 
risk taking. ${ }^{63}$ For banks, limited liability was introduced later, in 1857 with the repeal of the 1844 Act. The repeal also enabled joint-stock bank promotion to re-start.

Dissatisfaction with the 1844 Act had been growing. It was fuelled by continued failures within the few banks founded under its provisions and what were increasingly seen as overly restrictive measures pertaining to both note issuing and bank formation. In particular, the financial crisis of 1847 required the government to authorise the Bank of England to disregard the restriction of note issuing under the 1844 Act in order to reassure the business community. A financial crisis imported from America in late 1857 required similar action. ${ }^{64}$ Remaining instability in the banking system and the requirement of more liberal note issuing during crises thus persuaded the government to repeal the 1844 Bank Act and to introduce limited liability to banking.

The Companies Acts passed between 1857 and 1862 led to banks being able to register as limited liability companies. As such, the liability of bank directors and shareholders became limited to the size of their investment/share in the bank. ${ }^{65}$ These banks could be formed merely by registration and this sparked a promotion boom. Importantly the Companies Act of 1857 retained some of the restrictive clauses and capital requirements from the 1844 Act. $^{66}$

Responding to the new regulation, growth in banking services in the latter half of the nineteenth century owed much to a bulk of new promotions from the $1860 \mathrm{~s}$ onwards, as well as the expansion of existing companies. Many banks and their branch networks had already been established by 1844 and remained relatively unchanged. Others expanded again, albeit without the buoyancy and excitement of their initial branching activity. Joint-stock banking was no longer new in England and Wales, as in 1826, and both the banks and their customers had more confidence in institutions owned 
by numerous shareholders and with the capacity to branch. The story into the second half of the nineteenth century can be seen as one of continued but more gradual change. Thus, despite opposition and the 1844 legislation that restricted new joint-stock bank formations, the rise of joint-stock banks with branches began again from the 1860s.

If legislators disliked large branch networks so much, why not just prohibit them? A simple explanation exists and this point is entirely counterfactual. English law had never restricted the size or scope of branch networks. To make such a large change in the substance of regulation needed to be supported by a compelling argument. Even if this could be found, implementing such legislation and would have been difficult to say the least. By 1844, large branch networks had formed. Undoubtedly, these were unwanted by some. Yet, in order to remove them, parliament would need to pass retrospective legislation. Retrospective legislation was notoriously difficult to achieve as it was from a constitutional context thought to be inherently unjust. Individuals could not travel back in time to make different choices. However, in a banking context, proposals for retrospective legislation were not uncommon. It had made certain transactions, which might have been illegal, clearly legal. ${ }^{67}$ Passing legislation, which made past conduct illegal, would be an entirely different matter. Policy-makers were, therefore, left with an ambition to influence future, not past, conduct and to operate within the confines of the current regulatory system. In short, they could use the traditional mechanisms to control behaviour, such as imposing barriers to promoting new firms, denying corporate status, and providing disincentives through altering the cost of licences.

Although the legislation here was complex and ever changing, one point did not change in this period: legislators thought that banks were supposed to be small in scale 
and also in terms of geographical spread. The first legislators did not anticipate the size of joint-stock banking and its propensity to develop branches. Bankers succeeded in pushing through legislation which allowed them to form a national network and took the opportunity to do so. Following the failure of some ambitious branchers (the Northern and Central Bank in 1836 and the Yorkshire District Bank in 1840), legislation was passed in 1844 which aimed to restrict the pace at which these banks expanded. But the Bank Charter Act 1844 was enacted after distinct changes had taken place. In particular many banks by this point had taken the opportunity to establish branch networks. It therefore could not remove them in their entirety. After the Act's repeal in 1857, expansion could (and did) begin again with few barriers to entry.

Having examined the regulatory environment surrounding joint-stock banks, the next section goes on to examine a case study of a bank that branched in order to shed light on the branching strategy of banks in this period.

Insert Table 2 here

\section{Regional banking strategy}

The following section uses Manchester and Liverpool District Bank as an example in order to explore the reasons behind the shape of its network. This case study will provide more detail with regard to the branching activity of a typical regional/district bank. By using this case study, this section will discuss the bank's strategy; its motivations behind a regional strategy; and some factors which prevented extra-regional expansion. In doing so, it will examine the advantages and disadvantages of having a 
branch network and offer some conclusions as to why it branched and did not remain a single unit, yet why it did not extend to a national scale.

Manchester and Liverpool District Bank was founded in 1829 and had a network of branches throughout the period that was large and sizeable. The bank began as the 'District Union Bank' without stipulating a clear or specific geographical remit in its name. So from its very conception, the bank was intended to serve a broad geographical area but it was always focussed upon the cities of Manchester and Liverpool and the surrounding region. ${ }^{68}$ It was therefore a district and not a national bank, as reflected in both its original and revised name. With a head office in Manchester, after foundation it earmarked fourteen other smaller locations to branch in and expanded into these areas and beyond with quick succession (all eventual branch locations plotted on Figure 2).

Why open branches and not form as a single unit? Branches have sometimes been viewed as part of a "single unit plus" strategy. In this sense, branches supported the main hub of the business and acted as a form of advertising for the core of the business; another means to attract new customers at the centre. ${ }^{69}$ Although the branches in the network may not have been even in size or profitability, they would act as a supportive structure for its central location and act to enlarge the business flowing through the main branch or head office.

The principal reason why the Manchester and Liverpool District Bank created and maintained a large network was to seek out new deposit taking, note issuing and lending in new places outside a central or key location. Table 3 shows that a large proportion of account holders were found in the area outside the head office in Manchester. Thus branching allowed the bank to access new sources of capital and 
finance outside this city. With this strategy in place, capital would then flow from one place to another, and if necessary back to the centre.

Branches found customers in towns and villages, essentially in locations where the population was small but, importantly, sufficiently wealthy. Table 3 shows that Stockport held an unusually high number of depositors yet in terms of net average contribution this was not an especially prosperous area. Those in Bury, by comparison, deposited on average $£ 703$ - more than those in the prosperous areas of Manchester and Liverpool. Gilbart, the manager of London and Westminster joint-stock bank, explained the key motivation for branch locations. It would 'be opened in places not sufficiently wealthy to furnish capital for a joint-stock bank, and where the people have no banking facilities' ${ }^{70}$ Thus a branch could be established in a location where it was not financially viable to establish a full bank. Manchester and Liverpool, as large commercial centres, were not short of wealthy people but the areas outside these cities held customers that would also be desirable to the bank. ${ }^{71}$

As the bank began its formation in 1829 , without intense competition, it had a first mover advantage in terms of filling physical space. ${ }^{72}$ Threats to open a new rival bank in Bury in 1832 forced the bank to think immediately about opening a branch there. Within two months, this process was complete. ${ }^{73}$ As opening a branch could be quick and relatively cheap, in comparison to promoting a whole new bank, the Manchester and Liverpool District Bank was able to fend off competition and rival single units. Indeed, as Table 3 suggests, the local economy held considerable wealth and offered opportunities for sustainable growth.

INSERT TABLE 3 
In this process of rapid expansion, poor local knowledge could prevent further expansion and maintenance of the network. Yet this should be separated clearly from issues of education, training and literacy. Thomas Kinnersley acted as the manager for the Newcastle-under-Lyme branch but after his death in 1855, the bank simply gave up with the branch. The Board considered that if it had not been for "Mr Kinnersely's death it [the branch] would have succeeded" ${ }^{74}$ Thomas Kinnersley was theoretically replaceable. Indeed, with around thirty other branches, the bank had staff with equal levels of training and education. Kinnersley's uniqueness lay in the fact that he had been a private banker before conversion of his bank to a branch of the Manchester and Liverpool District Bank, and subsequently his appointment as branch manager. $\mathrm{He}$ therefore possessed knowledge of his local community and the creditworthiness of customers that would be advantageous to the bank. For the bank, closing Kinnersley's old branch did not mean a loss of custom as several moved to existing branches close by in Hanley.

Taking over or merging with existing private banks overcame the problems which inhibited expansion, namely lack of local knowledge and banking expertise. As the Kinnersley example demonstrates, it was a way to achieve geographical size with relatively few risks. As private banks had already built a customer base and reputation, merger was a simple way to strengthen the acquirer's commercial position and therefore create a large and sizeable geographical spread. Yet, unless the branch could prove to be successful, it would be closed.

Although the Manchester and Liverpool District Bank engaged in mergers with smaller banks in the region, it did not spread itself across the nation. But it did enter 
neighbouring counties. Branches formed in towns and villages not geographically very distant but over the county boundary of Lancashire (where Manchester and Liverpool were located), such as Stone and Newcastle-under-Lyme in Staffordshire in the West Midlands. It did, however, avoid moving further afield to major commercial areas and cities such as Birmingham, as shown in Figure 2.

Additional branches tended to be formed in the main through a cautious policy of sub-branching. A sub-branch existed as an attachment to a branch rather than an independent branch in its entirety. ${ }^{75}$ So for the sub-branch, the branch staff would visit for a few hours or days in the week. In some instances, this rather careful policy proved successful and some sub-branches were converted into full and separate branches. ${ }^{76}$ This was a good way of trying out a location before committing more fully to establishing a branch there. This strategy imitated that of the National Provincial Bank of England as it sought to explore and essentially overbank its existing regions and largely ignore the others with which the bank remained unfamiliar. Prudence ultimately meant that the bank did not achieve a wide geographical spread.

As a result of the principal focus on Manchester and Liverpool and the neighbouring region, the Manchester and Liverpool District Bank was susceptible to regional shocks. The reliance on a single regional economy caused several problems. The North West and Lancashire region were both highly dependent on the cotton industry. ${ }^{77}$ When in 1865 , the bank's Managing Director calculated a high number of bad debts he 'had the satisfaction of feeling that none of them [could be] attributed to their negligence of want or judgment'. He explained that they were 'mainly the necessary and unavoidable consequence of the accumulated losses which have arisen from the deficiency of cotton'. ${ }^{78}$ With a cautious local branching strategy, the Board 
accepted that problems in the local economy created instability in its own business. Although the bank was careful not to be over reliant on a single customer, a high proportion of the population it serviced found employment or owned businesses in cotton and its related industries during this period. ${ }^{79}$ Such regional industrial specialisation was bound to have an impact on the banks that serviced the community.

How could a bank be strengthened against such shocks in local and regional economies? It remains overwhelming clear from the Board minutes that the bank, at this stage in its history, did not engage in a serious discussion about merging with another large regional or district bank to create a multi-regional or even national bank. ${ }^{80}$ It did not, like other banks, exchange information or business with banks in other regions. ${ }^{81}$ The Manchester and Liverpool District Bank instead sought to expand on a smaller scale through existing channels - at the peripheries - but only if its management felt that the move would be successful and likely to be met with an influx of new custom. Longdistance branching seemed to be unthought-of and it settled for a regional profile in an area with ample opportunity for profit and expansion.

\section{Conclusions}

Geographical expansion through branching has been viewed as most significant in UK banking during the merger movement from the 1880 s to the 1890 s, when the average network exceeded 100 branches per bank, and when private banking was almost completely eclipsed. ${ }^{82}$ Yet this dataset has shown that there was much more branching in the period prior to the amalgamation movement, especially before 1836 , than has previously been acknowledged. Lack of banking education and banking skills did little to halt the pace of expansion. Moreover, the data analysed here shows that the process 
of branching was much more nuanced, fractured and non-linear than has previously been thought. Banks expanded branch networks but also sometimes retracted them.

This expansion was, in some cases, on a large-scale and despite the best efforts of regulators to curb their enthusiasm for expansion and instead foster the operation small banks with limited branching activity. To be clear, legal rules did not prohibit the growth of formulation of a national or large network. However, legal rules are best understood in the context in which they were created. Policy makers, politicians and lawyers act together to ascribe a meaning or value to the words used to create legal rules. Contemporaries who followed the debate and their language would nevertheless have understood sentiments and intention, which may not be plain and clear in the letter of law. Indeed, bankers did follow this debate and legal changes with interest. Although not prohibited by law, banking policy sought to reduce the size of branch networks at many points throughout the nineteenth century.

After gaining the legal ability to create a network in the provinces from 1826 and nationally from 1833, banks pursued energetic, vigorous and aggressive branching strategies but this initial enthusiasm was short-lived. Regulation and negative political pressure from legislators curbed ambition after 1836. But it was not the end of branch banking. By 1836, branch networks had proved to be sizeable and growing. Indeed, in some cases, they had branched and expanded well beyond the bank's original intentions and place of birth. Yet, following the failure of the Northern and Central Bank in 1836, and the political aftermath, this changed: networks contracted and branching strategies became less evolutionary. Several banks formed before 1844 did not regain this enthusiasm for mass or aggressive extra-regional expansion. 
For many formed before 1844, such as the Manchester and Liverpool District Bank, expansion thereafter took place at a piecemeal rate throughout existing regions or by discreetly and cautiously entering into new areas. Ambitious geographical expansion and the formation of a truly national bank were no longer on the agenda. Even National Provincial Bank of England, established in 1833, which in its name purported to become both a national and provincial bank, was only a provincial bank with a wide network of branches across many regions but not with what could be called a truly national coverage. For those banks formed before 1844, while the networks were large, gaps in the regional market were still visible and provided ample opportunity for new business. National Provincial's network, for example, displayed large gaps in the North West and Yorkshire. Moreover, if there were still profitable gaps left to fill on the banking map at a regional level, there was not the spur to form a national bank with the potential risks that this entailed. Thus, a bank with nationwide branch coverage did not develop before 1857 .

By the second half of the century, competition gained intensity and it was up to the new banks formed under limited liability legislation of 1857 to break this provincial focus and begin a multi-regional programme of expansion. Under this new strategy, banks pushed out from London and gained new territory through branching. It was the new banks that looked outwards from London and which threatened and sparked a competitive drive from the pre-existing banks. Thus there was a movement towards a national agenda that was ultimately fulfilled at the start of the twentieth century. Indeed, once many of the gaps in the market for banking had been filled following bank expansion after 1857, the spur for greater market control came from these ambitious banks that gained a geographical advantage through multi-regional branching. 
Therefore, it was increasing competition and pressure for market share, as the banking map of England and Wales became increasingly 'filled', that resulted in joint-stock banks national branch networks by 1900 .

The rhythmic nature of branch banking expansion can in many ways be attributed to changes in English law. The Acts passed in 1844 put a break on expansion. Nevertheless, joint-stock banks pushed back against such negative legal sentiment and still engaged in branch banking. Banks had, during the first half of the nineteenth century, established relatively large and complex branch networks which would constitute the core basis of their business for the remainder of the century. It provided the experience of managing banking business through branches that later led to the successful establishment and operation of national branch networks by London based banks in the late-nineteenth century. Most notably, after serious political pressure against branch banking, they did not bow to legal rules or intent and return to the single unit model. Some banks remained as single units up to 1877 , but these were very few in numbers. While banks either did not have or gave up a national ambition by finding plenty of opportunity for profit locally, our findings show that English and Welsh banks engaged entrepreneurially in branching and established large networks well before the merger movement of the 1880 s despite the apparent risks.

Acknowledgements:

This work was supported by the Economic and Social Research Council [grant number: ES/J500148/1] and Leverhulme Trust of the research project F.2121: 'The constituencies of English and Welsh domestic joint stock banks, 1826-1885'. We a considerable debt of gratitude to the archivists who assisted in the collection of data 
used in this paper, especially Jesse Campbell, Edwin Green, Sara Kinsey, Karen Sampson, Susan Snell, Alison Turton, and Philip Winterbottom. We would also like to thank the two anonymous referees for their constructive feedback and those that commented on an earlier drafts of this paper: Peter Scott, Peter Wardley, PierreGuillaume Méon, those at the Association of Business Historians Conference in Preston in 2013, the workshop at Queen's University Centre for Economic History in Belfast in 2013; the Business History Conference in Frankfurt am Main in 2014, and the workshop of the European Association for Banking and Financial History in Brussels in 2015. 


\section{References}

\section{Official reports}

Stamp Act 181555 Geo 3. c. 184

Banking Co-partnership Act 18267 Geo. IV c. 46

The Bank Charter Act 18447 \& 8 Vict. c. 32

Joint-Stock Bank Act 18447 \& 8 Vict. c. 113

Joint-stock Banking Companies Act 20 \& 21 Vict. c. 49

Report of the Committee of Secrecy on the Bank of England charter (P.P. 1832, VI)

Select Committee Report on Joint-Stock Banks (P.P. 1836, IX).

Select Committee Report on Joint-Stock Banks (P.P. 1837, XIV).

Select Committee Report on Joint-Stock Banks (P.P. 1838, VII).

Return of Joint-stock Banks established under 7 Geo. IV c. 46 (P.P. 1844, XXXII)

Account of the number of joint-stock banking companies that have been established under the act 7 Geo. 4. c. 46. (P.P. 1826-27, XX, 544)

An account of places where united or joint-stock banks have been established, under the act 7 Geo. IV. c. 46. (P.P. 1830, XXX, 455)

An account of places where united or joint-stock banks have been established under the act 7 Geo. IV. c. 46 (P.P. 1833, XXIII, 351)

An account of all places where united or joint-stock banks have been established under the act 7 Geo. IV. c. 46 (1836, XXXVII, 172)

Return of the joint-stock banks existing in England and Wales, in each of the three years ending 5 January 1839. Similar returns for Scotland and Ireland. (1839, XXX, 530). 
An account of the number of private and joint-stock banks registered in each year from 1820-1842 (P.P. 1842, XXIII, 85)

An account of all the joint-stock banks existing in England and Wales registered in each year from 1840-1842 (P.P. 1842, XXIII, 35)

\section{Trade Journals}

The Bankers' Magazine (1844-1878)

Banker Almanac (1844-1878)

Fenn's A compendium of the English and foreign funds, and the principal joint stock companies (1837)

\section{Archives}

HSBC Group Archives (HSBCGA)

Royal Bank of Scotland Group Archives (RBSGA)

Lloyds Bank Group Archives (LBGA)

Barclays Bank Group Archives (BBGA)

\section{Secondary Sources}

Armstrong, William Kingo, Memoir of John Ross Coulthart of Ashton-under-Lyne, In the County of Lancaster, Forty Years of the Ashton, Stalybridge, Hyde and Glossop Bank. Edinburgh: McFarlane \& Erskine, 1876.

Berger, A. N. and A. A. Dick, "Entry into banking markets and the early-mover advantage", Journal of Money, Credit and Banking 39, no. 4 (2007) 775-807.

Bielski, Lauren, “Branch building spree: hitting saturation?”, ABA Banking Journal, August 2005, Vol. 97, Issue 8, pp. 36-44. 
Bodenhorn, Howard, A History of Banking in Antebellum America: Financial Markets and Economic Development in an Era of National-Building. New York: CUP, 2000.

Burton, Dawn, David Knights, Andrew Leyshon, Catrina Alferoff, and Paola Signoretta. 'Consumption Denied? The Decline of Industrial Branch Insurance'. Journal of Consumer Culture 5, no. 2 (1 July 2005): 181-205.

Cameron, Rondo (ed.), Banking in the Early Stages of Industrialization: a study in Comparative Economic History. London: OUP, 1967.

Capie, Forrest, and Michael Collins. "Industrial Lending by English Commercial Banks, 1860s-1914: Why Did Banks Refuse Loans?” Business History 38, no. 1 (January 1, 1996): 26-44. doi:10.1080/00076799600000002.

Capie, Forrest and Ghila Rodrik-Bali, "Concentration in British Banking 1870-1920” Business History 24, No. 3 (1982): 280-292.

Collins, Michael, and Mae Baker. Commercial Banks and Industrial Finance in England and Wales, 1860-1913. Oxford: Oxford University Press, 2003.

Cottrell, P. L. Industrial Finance 1830-1914. London: Methuen, 1979.

Cottrell. Philip L., “'Conservative abroad, liberal at home': British Banking Regulation during the Nineteenth Century." In State and Financial Systems in Europe and the USA: Historical Perspectives on Regulation and Supervision in the Nineteenth and Twentieth Centuries, edited by Stefano Battilossi, Jaime Reis, 21-40. London: Ashgate Publishing Ltd, 2010.

Cottrell, P. L. "Banking and Finance.” In Atlas of Industrializing Britain, 1780-1914, edited by John, Langton and, R.J., Morris. New York: Methuen, 1986. 
Crick, W. F. and J. E. Wadsworth. A Hundred Years of Joint-stock Banking. London: Hodder \& Stoughton 1936.

Crafts, Nicholas and Nikolaus Wolf, 'The Location of the UK Cotton Textiles Industry in 1838: A Quantitative Analysis', The Journal of Economic History 74, No. 4 (2014): 1103-1139

Dennett, Laurie. Sense of Security: 150 Years of Prudential. Cambridge: Granta Editions, 1998.

Dick, Astrid A., "Market size, service quality, and competition in banking”, Journal of Money, Credit and Banking 39, no. 1 (2007): 49-81.

Farnie, D. A., The English Cotton Industry and the World Market, 1815-1896. Oxford: Clarendon Press, 1979.

Gerschenkron, Alexander. Economic Backwardness in Historical Perspective: A Book of Essays. Belknap Press of Harvard University Press, 1962.

Gilbart, James-William, The history and principles of banking. London: Longman, 1837.

Green, Edwin. Debtors to their profession. London: Methuen, 1979.

Gregory, T. E. Westminster Bank through a century, Vol. 1, London: Westminster Bank Ltd., 1936.

Greve H., "Market niche entry decisions: competition, learning and strategy in Tokyo banking, 1894-1936”, Academy of Management Journal 43, no. 5 (2000): 816836.

Grossman, Richard S., Unsettled Account: The Evolution of Commercial Banking in the Industrialized World since 1800. New Jersey: Princeton University Press, 2010. 
Henderson, William Otto. The Lancashire Cotton Famine 1861-6. Manchester:

Manchester University Press, 1934

Heim, Carol E. 'Industrial Organization and Regional Development in Interwar Britain'.

The Journal of Economic History 43, no. 4 (December 1983): 931-52.

Holmes, A.R. and E. Green, Midland. London: Batsford, 1986.

Hudson, Pat. "The Role of Banks in the Finance of the West Yorkshire Wool Textile Industry, c. 1780-1850” Business History Review 55, no. 3 (1981): 379-402.

Hunt, Bishop C., “The Joint-Stock Company in England, 1830-1844” Journal of Political Economy 43, no. 3 (1935): 331-364.

Jefferys, James B. Retail Trading In Britain 1850 1950. Cambridge: Cambridge University Press, 1954.

Jones, Geoffrey. British Multinational Banking, 1830-1990. Clarendon Press, 1995.

- Multinationals and Global Capitalism: From the Nineteenth to the Twenty First Century: From the Nineteenth to the Twenty First Century. OUP Oxford, 2004.

Joplin, Thomas, An examination of the report of the joint-stock bank committee.

London: J. Ridgway and Sons, 1837.

Kennedy, William P. Industrial Structure, Capital Markets and the Origins of British Economic Decline. CUP Archive, 1987.

Knight, Frank Hyneman. Risk, Uncertainty and Profit. Houghton Mifflin Company, 1921.

Lamoreaux, Naomi. Insider Lending: Banks, Personal Connections, and Economic Development in Industrial New England. New York: Cambridge University Press, 1996. 
Larson, Mitchell J., Karen Ward, and John F. Wilson. "Banking from Leeds, Not London: regional strategy and structure at the Yorkshire Penny Bank, 18591952”. Accounting, Business \& Financial History 20, no.2 2010 117-133

Lieberman, M. and D. Montgomery, "First Mover Advantages", Strategic Management Journal 9, no. 2 305-327.

Marston Acres, W. The Bank of England from Within 1694-1900 Volume II. London: OUP, 1931

Morris, William, Swindon Fifty Years Ago, More Or Less: Reminiscences, Notes, and Relics of Ye Old Wiltshire Towne. Swindon: The Advertiser Office, 1885.

Munn, Charles. "The Emergence of Joint-Stock Banking in the British Isles a Comparative Approach", Business History 30, no. 1 (1988) 69:83.

Munn, C.W. The Scottish Provincial Banking Companies 1747-1864. Edinburgh: John Donald, 1981.

Newton, Lucy and P. L. Cottrell. "Banking in the English provinces, 1826-1857: to branch or not to branch?” Business and Economic History 27, no. 1 (1998): 115128.

Newton, Lucy, "The Birth of Joint-stock Banking: a Comparison of England and New England in the Nineteenth Century" Business History Review 84, no. 1 (2010): $27-52$.

Newton, L. A., "Regional bank-industry relations during the mid-nineteenth century: links between bankers and manufacturing in Sheffield", Business History 38, no. 3 (1996): 64-83. 
Newton, Lucy, "English banking concentration and internationalisation: contemporary debate, 1880-1920", in International banking in an age of transition, edited by Sara Kinsey and Lucy Newton, 57-89. London: Aldershot, 1998.

Prescott, E. C. and M. Visscher, "Sequential location among firms with foresight", Bell Journal of Economics 8, no. 2 (1977) 378-393.

Pressnell, Leslie. Country Banking in the Industrial Revolution. Oxford: Clarendon Press, 1956.

Rae, George, The Country Banker 1885. 1976 edition, Pentagon Books.

Sayers, R. Lloyds Bank in the History of English Banking Oxford: Clarendon Press, 1957.

Schmalensee, R., "Entry deterrence in the ready-to-eat breakfast cereal industry", Bell Journal of Economics, 1977, 9, pp. 305-327.

Smith, Adam. An Inquiry Into the Nature and Causes of the Wealth of Nations. Printed at the University Press for T. Nelson and P. Brown, 1827.

Sykes, Joseph, The Amalgamation Movement in English Banking 1825-1894 London: P.S. King and Son, 1926.

Taylor, James, Creating Capitalism: Joint-Stock Enterprise in British Politics and Culture 1880- 1870. Suffolk: Boydell Press, 2006.

Timmins, Geoffery, Made in Lancashire: A History of Regional Industrialisation. Manchester: Manchester University Press, 1988.

Turner, John D., Banking in Crisis. Cambridge: Cambridge University Press, 2014. Turner, John D., 'The Last Acre and Sixpence': Views on Shareholder Liability Regimes in Nineteenth-Century Britain", Financial History Review 16, (2009) $111-28$ 
White, Eugene, “The Merger Movement in Banking, 1919-1933”, Journal of Economic History 45, no.2 (1985) 285-91

\footnotetext{
${ }^{1}$ Jones, Multinationals and Global Capitalism.

${ }^{2}$ Jones, British Multinational Banking, 1830-1990.

${ }^{3}$ Gerschenkron theorised that banks played a critical role in investing in industry and thus fostering economic growth. See Gerschenkron, Economic Backwardness in Historical Perspective.
}

${ }^{4}$ Kennedy, Industrial Structure, Capital Markets and the Origins of British Economic Decline.

${ }^{5}$ Newton and Cottrell. "Banking in the English provinces, 1826-1857: to branch or not to branch?”; Cottrell, “'Conservative abroad, liberal at home’: British Banking Regulation during the Nineteenth Century"

${ }^{6}$ Capie and Collins, "Industrial Lending by English Commercial Banks, 1860s-1914.”

${ }^{7}$ Here Knight's understanding of term 'entrepreneurship' is utilised. See Knight, Risk, Uncertainty and Profit.

${ }^{8}$ See for example, Grossman, Unsettled Account 78, Cameron, Banking in the early stages, 11-313. Cottrell, “'Conservative abroad, liberal at home': British Banking Regulation during the Nineteenth Century" 39.

${ }^{9}$ Here the Oxford English Dictionary definition of risk is used: 'A situation involving exposure to danger'.

${ }^{10}$ Grossman, Unsettled Account 238-40, 260, White, “The Merger Movement in Banking, 1919-1933”, Bodenhorn, A History of Banking in Antebellum America 31-44.

${ }^{11}$ Newton and Cottrell, "Banking in the English provinces, 1826-1857: to branch or not to branch?", 118.

${ }^{12}$ This excludes the London agency relationship and these agents performed different functions.

${ }^{13}$ Bankers Almanac explained in 1914 that 'The proportion of offices not opened daily has increased in England and Wales. From being about one-twelfth in the years 1886-1888 it is now nearly one-quarter of the whole number [6,709]'Banker Almanac, 1914. 
${ }^{14}$ See Newton, "Regional bank-industry relations during the mid-nineteenth century: links between bankers and manufacturing in Sheffield".

${ }^{15}$ Smith, An Inquiry Into the Nature and Causes of the Wealth of Nations, 311-12.

${ }^{16}$ Heim, "Industrial Organization and Regional Development in Interwar Britain".

${ }^{17}$ Dennett, A Sense of Security: 150 Years of Prudential

${ }^{18}$ Burton, Knights, Leyshon, Alferoff and Signoretta "Consumption denied? The decline of industrial branch insurance", 192.

${ }^{19}$ Jefferys, Retailing in Britain, 1850-1950 21-25.

${ }^{20}$ Ibid, 26.

${ }^{21}$ Ibid, 31 .

${ }^{22}$ Newton and Cottrell. "Banking in the English provinces, 1826-1857: to branch or not to branch?".

${ }^{23}$ Crick and Wadsworth, A Hundred Years of Joint-stock Banking, 7

${ }^{24}$ In 1798, 298 private banks were single units, whereas just 14 had two or more offices. For more detail see, Pressnell, County banking, 9-10, 126-135.

${ }^{25}$ Hudson, "The Role of Banks in the Finance of the West Yorkshire Wool Textile Industry, c. 1780$1850 "$ ".

${ }^{26}$ Lamoreaux, Insider Lending, 162.

${ }^{27}$ Sayers, Lloyds, 237

${ }^{28}$ Collins and Baker, Commercial Banks, 159

${ }^{29}$ The Nottingham and Nottinghamshire Banking Company appointed Mr Peter Watt, an experienced banker from Edinburgh, to be their first Manager. The Westminster Bank, established in 1833, appointed Gilbart as their manager, who had previously been employed as manager of the Provincial Bank of Ireland's branches at Kilkenny and Waterford. LBGA, Board of Directors Minutes, 574, $4^{\text {th }}$ March, 1834. Gregory, Westminster, 96-7. More generally, Munn, "The Emergence of Joint-Stock Banking in the British Isles: a Comparative Approach".

${ }^{30}$ Scottish banks ventured outside of Scotland and set up branches in the North West of England. Scottish banks also had many more branches than their English and Welsh counterparts, possibly due to the greater dispersal of population in Scotland as compared to England (where the population was 
concentrated and urbanised) and due to their long tradition of using agents. Irish branch networks, by comparison, were larger than the English and Welsh but smaller than their Scottish counterparts. But by 1875, the number of bank offices per capita was very similar in England and Ireland. The difference between all four countries in Great Britain was largely expunged by 1913. Collins, Money and Banking, 56-7 and 75-6. Munn, The Scottish Provincial Banking Companies 1747-1864, 177-8. Munn, "The Emergence of Joint-Stock Banking in the British Isles a Comparative Approach"

${ }^{31}$ Sayers, Lloyds, 63. See also Hunt, "The Joint-Stock Company in England, 1830-1844" 345, Crick Wadsworth, A Hundred Years of Joint-stock Banking, 9.

${ }^{32}$ Collins, Money and Banking, 85-6, Green, Debtors to their profession, Holmes and Green, Midland, 64.

${ }^{33}$ See Capie and Ghila Rodrik-Bali, "Concentration in British Banking 1870-1920"Sykes, The Amalgamation Movement in English Banking, Chapters 8 and 9, Newton, "English banking concentration and internationalisation: contemporary debate, 1880-1920",

${ }^{34}$ Birmingham and Midland moved their head office from Birmingham to London in 1891; Lloyds and the Birmingham Banking Company moved from Birmingham to London in 1884 and 1889 respectively; and Barclays moved to London in 1896. The remaining two of the Big Five - the National Provincial and Westminster Bank - had been based in London from their formation. A London head office allowed membership of the London Clearing House, and subsequent benefits, but also was a strategy to keep up with the behaviour of competitors. Holmes and Green, Midland, 57 and 79.

${ }^{35}$ William Waterston, A Cyclopaedia of Commerce, Mercantile Law, Finance, Commercial Geography, and Navigation, 58

${ }^{36}$ Thomas Joplin, An Examination of the Report of the Joint Stock Bank Committee \&c. ... 44

${ }^{37}$ See Cottrell, "Banking and Finance."

${ }^{38}$ These results bear comparison with early branching in Tokyo, where most banks in their early period of branching only founded 9 or fewer branches but that branching increased over time. H. Greve, "Market niche entry decisions".

${ }^{39}$ Dataset.

${ }^{40}$ Report of the Secret Committee on Joint Stock Banking PP, 1836, IX, 222.

${ }^{41}$ See in particular evidence from those associated with the Bank of England. Select Committee Report on Joint-Stock Banks (P.P. 1836, IX), Select Committee Report on Joint-Stock Banks (P.P. 1837, XIV)

${ }^{42}$ Armstrong, Memoir, 61

${ }^{43}$ Gilbart, The history and principles of banking, 135, 82 
${ }^{44}$ HSBCGA: Prospectus of the Huddersfield Banking Company, H41/18, $9^{\text {th }}$ March 1827.

${ }^{45}$ In contrast, Figure 2 shows the London and County servicing London and the Home Counties alone.

${ }^{46}$ Cottrell, Industrial Finance, 195.

${ }^{47}$ For more theoretical considerations regarding entrance and location, see Prescott and Visscher,

"Sequential location among firms with foresight", 378-393, Schmalensee, "Entry deterrence in the readyto-eat breakfast cereal industry", 305-327.

${ }^{48}$ Provincial Banking Company was not connected to well-established National Provincial Bank of England despite the similarities in name. London and Provincial described the firm's network more accurately. Indeed, banks tended to change in name after expansion and additions to their network.

${ }^{49}$ This strategy links to modern banking where research has found that geographical diversity is an advantage to banks, especially new entrants. Berger and Dick, 'Entry into banking markets and the early-mover advantage".

${ }^{50}$ Rae, The Country Banker, 287.

${ }^{51}$ See Bielski, Lauren, "Branch building spree: hitting saturation?”, ABA Banking Journal, August 2005, Vol. 97, Issue 8, 36-44.

${ }^{52}$ Gilbart, The history of banking in America, 82-83.

${ }^{53}$ Banking Co-partnership Act 18267 Geo. IV c. 46.

${ }^{54}$ Gregory, Westminster, Chapter 4 for London generally. Outside London, Acres claimed that despite the Bank warning North Wiltshire Bank that its branch in Hungerford was within the 65-mile radius, it persisted in opening its branch in Hungerford but it was only open for a year. In Morris's history of Swindon, he revealed that it was the Bank of England's special privileges which 'caused the [bank's] scheme to be abandoned' after it was found to be just within a half a mile of the radius. Morris, Swindon Fifty Years Ago, 266; Acres, The Bank of England, 500.

55 Stamp Act 55 Geo 3. c. 184 s 24. 
${ }^{56}$ Select Committee Report on Joint-Stock Banks (P.P. 1836, IX). Select Committee Report on JointStock Banks (P.P. 1833, IX).

${ }^{57}$ Gilbart, in his account of banking history, did much to publicise and explain the regulation of branch networks. Gilbart, The history and principles of banking, 110.

${ }^{58}$ Bank Charter Act 18333 \& 4 Wm. IV c. 98.

${ }^{59}$ See for example Report of the Secret Committee on Joint-stock Banking PP, 1837, XVII, 23.

${ }^{60}$ The Bank Charter Act 18447 \& 8 Vict. c. 32, Joint-Stock Bank Act 18447 \& 8 Vict. c. 113

${ }^{61}$ Without a verbatim copy of the parliamentary debates, considerable differences in reporting existed between sources. Reporters attended the debates and took notes. A copy was then published in the London newspapers. Hansard cobbled together its record from these sources. The quote here appears from the speech reported by Bankers' Magazine. It is not clear whether the magazine sent its own reporter to hear the debate or simply created its own version by interpreting the words within the newspaper's account. Nevertheless, Peel's words, in Hansard appeared to be less critical of banking behaviour than those in by Bankers' Magazine. Despite the differences in sources, and perhaps even in Peel's actual words, it is clear that bankers perceived, or at least were told, that policy-makers did not approve of large networks. The Bankers' Magazine, Volume 1, 202 Parliamentary Debates, series 3, Volume 74, col. 1335-1341, 20 May 1844 (House of Commons).

${ }^{62}$ Cottrell, Industrial Finance, 34.

${ }^{63}$ Taylor, Creating Capitalism, 150-64.

${ }^{64}$ Crick and Wadsworth, A hundred years, 28-29..

6520 \& 21 Vict. c. 49; Cottrell, Industrial Finance, 52-3.

${ }^{66}$ Cottrell, Industrial Finance, 50-53; Turner, "The Last Acre and Sixpence"

${ }^{67}$ A case in the Exchequer prompted the introduction of a bill intended to retrospectively permit clergymen to own shares. Hitherto, it had been thought illegal to do so. For a general summary of the debate and the importance of retrospective legislation, see Mirror of Parliament (Second series, volume 2, 1837-8) 6 February 1609-11. 
${ }^{68}$ RBSGA: Manchester and Liverpool District Bank Board of Directors Minutes 1, DIS/25/1 (18th April $1829-31^{\text {st } J u l y ~ 1839) . ~}$

${ }^{69}$ RBSGA: Manchester and Liverpool District Bank Board of Directors Minutes 1, DIS/25/1 (18th April $1829-31^{\text {st }}$ July 1839$)$.

${ }^{70}$ Gilbart, The history and principles of banking, 135.

${ }^{71}$ Turner provides an examination of shareholder's wealth more generally. Turner, Banking in Crisis, in particular Chapter 5.

${ }^{72}$ See also Schmalensee, 'Entry deterrence in the ready-to-eat breakfast cereal industry'; Lieberman and Montgomery, 'First Mover Advantages'.

${ }^{73}$ RBSGA: Manchester and Liverpool District Bank Board of Directors Minutes 1, DIS/25/1 (18th April $1829-31^{\text {st }}$ July 1839 ).

${ }^{74}$ RBSGA: Manchester and Liverpool District Bank Board of Directors Minutes 3, DIS/25/3 $\left(26^{\text {th }}\right.$ January $1859-15^{\text {th }}$ September 1871$)$.

${ }^{75}$ The bank's articles of association outlined that the procedure required open and close a branch was two successive meetings of the Board but this was not always carried out. RBSGA: Manchester and Liverpool District Bank Board of Directors Minutes 1, DIS/25/1 (18th April $1829-31^{\text {st }}$ July 1839$)$.

${ }^{76}$ This practice took place from the outset with the transformation of Stalybridge from subbranch to branch in 1832. RBSGA: Manchester and Liverpool District Bank Board of Directors Minutes 1, DIS/25/1 (18th April $1829-31^{\text {st } J u l y ~ 1839) . ~}$

${ }^{77}$ Farnie, The English Cotton Industry and the World Market, chapter 2. Crafts and Wolf, "The Location of the UK Cotton Textiles Industry in 1838: A Quantitative Analysis".

${ }^{78}$ RBSGA: Manchester and Liverpool District Bank Board of Directors Minutes 3, DIS/25/3 (26th January $1859-15$ th September 1871). For more discussion of the crisis in the cotton industry, see Henderson, The Lancashire Cotton Famine 1861-65.

${ }^{79}$ See also Timmins, Made in Lancashire: A History of Regional Industrialisation. 
${ }^{80}$ During the early years of joint-stock banking the Manchester and Liverpool District Bank sought to establish a branch in Birmingham. This plan was fairly short-lived as the individuals the Manchester bank approached, set up their own bank instead. Crick and Wadsworth, 54.

${ }^{81}$ RBSGA: Manchester and Liverpool District Bank Board of Directors Minutes 1, DIS/25/1 (18th April $1829-31^{\text {st }}$ July 1839). For a discussion of banks sharing information see Newton, Birth, 40.

${ }^{82}$ Cottrell, Industrial Finance, 197. 